\title{
ECOGRAPHY
}

\section{Breaking down the barrier: dispersal across the Antarctic Polar Front}

\begin{tabular}{|c|c|}
\hline Journal: & Ecography \\
\hline Manuscript ID & ECOG-02449.R1 \\
\hline Wiley - Manuscript type: & Brevia \\
\hline Date Submitted by the Author: & $\mathrm{n} / \mathrm{a}$ \\
\hline Complete List of Authors: & $\begin{array}{l}\text { Fraser, Ceridwen; Australian National University, Fenner School of } \\
\text { Environment and Society } \\
\text { Kay, Geoff; Australian National University, Fenner School of Environment } \\
\text { and Society } \\
\text { du Plessis, Marcel; University of Cape Town, Department of Oceanography } \\
\text { Ryan, Peter; University of Cape Town, Percy FitzPatrick Institute }\end{array}$ \\
\hline Keywords: & biogeographic barrier, Antarctica, kelp raft \\
\hline Abstract: & $\begin{array}{l}\text { Our view of the Antarctic Polar Front (APF) as a circumpolar biogeographic } \\
\text { barrier is changing (Chown et al. 2015). The APF marks the convergent } \\
\text { boundary between cold Antarctic water and warmer sub-Antarctic water, } \\
\text { and has long been considered to prevent north-south dispersal in the } \\
\text { Southern Ocean (reviewed by Clarke et al. 2005, Fraser et al. 2012). Our } \\
\text { multi-year survey data provides evidence that rafting organisms readily } \\
\text { cross the APF. }\end{array}$ \\
\hline
\end{tabular}

\section{SCHOLARONE}

Manuscripts

This is the peer reviewed version of the following article: Fraser, Ceridwen I., et al. "Breaking down the barrier: dispersal across the Antarctic Polar Front." Ecography 39 (2016): 001-003., which has been published in final form at https://dx.doi.org/10.1111/ecog.02449. This article may be used for non-commercial purposes in accordance with Wiley Terms and Conditions for Self-Archiving." 
Breaking down the barrier: dispersal across the Antarctic Polar Front

Ceridwen I. Fraser ${ }^{1 *}$, Geoffrey M. Kay ${ }^{1}$, Marcel du Plessis ${ }^{2}$ and Peter G. Ryan ${ }^{3}$

1. Fenner School of Environment and Society, Australian National University, Linnaeus Way, Acton, ACT 2601

2. Department of Oceanography, Marine Research Institute, University of Cape Town, Rondebosch, 7701, South Africa

3. Percy FitzPatrick Institute, DST-NRF Centre of Excellence, University of Cape Town, Rondebosch, 7701, South Africa

* Corresponding author: Ceridwen Fraser, email: ceridwen.fraser@gmail.com 
Our view of the Antarctic Polar Front (APF) as a circumpolar biogeographic barrier is changing (Chown et al. 2015). The APF marks the convergent boundary between cold Antarctic water and warmer sub-Antarctic water, and has long been considered to prevent north-south dispersal in the Southern Ocean (reviewed by Clarke et al. 2005, Fraser et al. 2012). Our multi-year survey data provides evidence that rafting organisms readily cross the APF.

The APF represents one of the main jets of the eastward-flowing Antarctic Circumpolar Current (Thompson 2008). Biological and oceanographic research in the last decade has not only provided an improved understanding of the APF, but has also begun to cast doubt on its ability to act as a barrier to dispersal. For example, past traverses of the APF have been inferred from molecular studies of molluscs (Page and Linse 2002) and crustaceans (Leese et al. 2010). Oceanographic data are also revealing that the APF is not a single, continuous circumpolar jet, but instead is dynamic and shifting, made up of many small jets (Thompson 2008). Furthermore, mesoscale eddies have been observed pushing through the APF, transporting parcels of sub-Antarctic water southwards (Ansorge and Lutjeharms 2003). Such eddies could carry marine organisms across the APF.

Despite indications that the APF is permeable on evolutionary timescales, evidence of frequent, contemporary movement of organisms across the front is lacking (Clarke et al. 2005). We hypothesised that the APF is regularly traversed by dispersing sub-Antarctic marine organisms which fail to establish in the colder, icier Antarctic environment. We tested this hypothesis by surveying the occurrence and density of floating sub-Antarctic kelp across the APF in the South Atlantic and Indian oceans. 
Two large, buoyant kelp species, Macrocystis pyrifera and Durvillaea antarctica, grow abundantly in the intertidal and shallow subtidal of the sub-Antarctic. These kelps occur almost exclusively north of the APF (see Supplementary Material, A1). Both species provide habitat for diverse marine invertebrates, which can be transported hundreds of kilometres by detached, floating kelp (reviewed by Fraser et al. 2012). Previous research has estimated that there are millions of kelp rafts drifting in the Southern Ocean (Smith 2002), and that they accumulate at frontal convergence zones (Garden et al. 2014). We therefore predicted that there would be more drifting kelp close to the APF than further away, but - under our hypothesis that the APF is highly permeable - there would be little difference in density above or below the APF.

We carried out three surveys in sub-Antarctic and Antarctic waters in the Indian and South Atlantic Oceans (see supplementary material A2 and A3, and Figure 1). Although both kelp species occurred at significantly higher densities in sub-Antarctic than Antarctic water, both were nonetheless found below the APF on all surveys (M. pyrifera: $\mathrm{F}=3.15, \mathrm{P}=0.002$, mean density Antarctic $=0.01$ per $\mathrm{km}^{2}$, sub-Antarctic $=0.06$ per $\mathrm{km}^{2} ;$ D. antarctica $: \mathrm{F}=4.28$, $\mathrm{P}=0.000$, mean density Antarctic $=0.01$ per $\mathrm{km}^{2}$, sub-Antarctic $=0.08$ per $\mathrm{km}^{2}$ ). Density of both species was higher closer to the APF than further away (M. pyrifera: $\mathrm{F}=-3.59, \mathrm{P}=0.000$; D. antarctica: $\mathrm{F}=-5.50, \mathrm{P}=0.000$ ), supporting our prediction of accumulation near the convergence zone.

Our observations of both kelp species south of the APF indicate that the front is not a strong barrier to dispersal for marine organisms. In particular, the large numbers of drifting $D$. antarctica south of the Condrad Rise, where the APF is known to split into two jets (Ansorge et al. 2008) and eddies can push through the front (Ansorge and Lutjeharms 2003), support the prediction of biological permeability of the APF. These observations are most likely to 
represent southward traverses of the APF of kelp from the Prince Edward Islands with observed eddies (see Supplementary Material, A1, for further discussion).

The discovery that the APF is permeable by shallow-water marine organisms indicates that oceanographic fronts are not the strong barriers to dispersal that they are often thought to be. Furthermore, our multi-year data suggest that traverses of the APF by rafting organisms are not rare; the probability of natural colonisations of Antarctica by shallow-marine organisms is therefore likely to increase as the climate warms and more sub-Antarctic and temperate species are able to survive in the high southern latitudes (e.g. see Byrne et al. in press).

Acknowledgments: see Supplementary Material, A4.

\section{References}

Ansorge, IJ and Lutjeharms, JRE. 2003. Eddies originating at the South-West Indian Ridge. Journal of Marine Systems 39: 1-18.

Ansorge, IJ et al. 2008. The first oceanographic survey of the Conrad Rise. - South African Journal of Science 104: 333-336.

Byrne, $\mathrm{M}$ et al. In press. From pole to pole: the potential for the Arctic seastar Asterias amurensis to invade a warming Southern Ocean. - Global Change Biology.

Chown, SL et al. 2015. The changing form of Antarctic biodiversity. - Nature 522: 431-438.

Clarke, A et al. 2005. How isolated is Antarctica? - Trends in Ecology \& Evolution 20: 1-3.

Fraser, CI et al. 2012. Poleward bound: biological impacts of Southern Hemisphere glaciation. - Trends in Ecology \& Evolution 27: 462-471.

Garden, CJ et al. 2014. Rafting dispersal constrained by an oceanographic boundary. Marine Ecology Progress Series 501: 297-302. 
Leese, F et al. 2010. Long-distance island hopping without dispersal stages: transportation across major zoogeographic barriers in a Southern Ocean isopod. Naturwissenschaften 97: 583-594.

Mazloff, M, Heimbach, P and Wunsch, C. 2010. An eddy-permitting Southern Ocean state estimate." - Journal of Physical Oceanography 40: 880-899

Page, T and Linse, K. 2002. More evidence of speciation and dispersal across the Antarctic Polar Front through molecular systematics of Southern Ocean Limatula (Bivalvia: Limidae). - Polar Biology 25: 818-826.

Smith, SDA. 2002. Kelp rafts in the Southern Ocean. - Global Ecology and Biogeography 11: 67-69.

Thompson, AF. 2008. The atmospheric ocean: eddies and jets in the Antarctic Circumpolar Current. - Philosophical Transactions of the Royal Society of London A: Mathematical, Physical and Engineering Sciences 366: 4529-4541.

Supplementary material: (Appendix EXXXXX at <www.oikosoffice.lu.se/appendix>). Appendix 1-5.

\section{Figure legend}

Figure 1: Top map: survey points, Indian Ocean 2008 (stars) and 2014 (triangles), and Atlantic Ocean 2013-2014 (circles), showing points at which M. pyrifera (yellow), D. antarctica (red) or both species (orange) were found. The position of the APF during each cruise is indicated (see legend in upper left of figure). Middle panel: mean (2005-2010) annual near-surface currents from the Southern Ocean State Estimation model (Mazloff et al. 2010). Lower panels: kelp densities by latitude. 

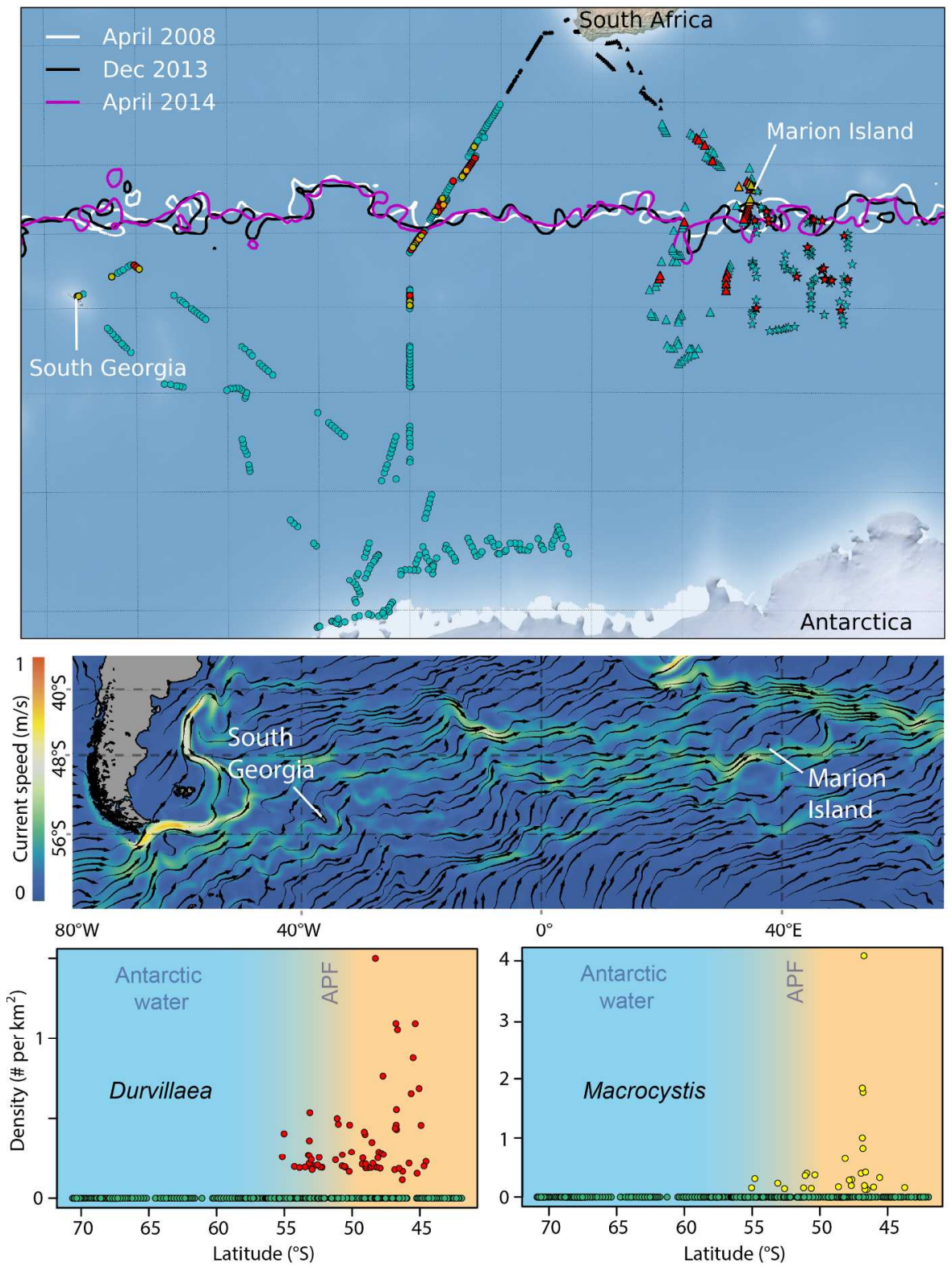

Figure 1: Top map: survey points, Indian Ocean 2008 (stars) and 2014 (triangles), and Atlantic Ocean 2013-2014 (circles), showing points at which M. pyrifera (yellow), D. antarctica (red) or both species (orange) were found. The position of the APF during each cruise is indicated (see legend in upper left of figure). Middle panel: mean (2005-2010) annual near-surface currents from the Southern Ocean State Estimation model (Mazloff et al. 2010). Lower panels: kelp densities by latitude. $204 \times 272 \mathrm{~mm}(300 \times 300 \mathrm{DPI})$ 


\section{Appendix 1 (A1): Kelp Distributions}

Both Durvillaea antarctica and Macrocystis pyrifera grow at high densities in the subAntarctic, and along the coasts of New Zealand and Chile (Fraser et al. 2009, Macaya and Zuccarello 2010), and have been shown to transport of a range of epifaunal organisms via rafting, including near the APF (e.g., Helmuth et al. 1994, Wichmann et al. 2012). Although there are some differences in their distributions, both are unable to survive in areas subject to frequent ice-scour (Fraser et al. 2009, Macaya and Zuccarello 2010), and so are not found below the Antarctic Polar Front, with the exception of two islands just south of the APF, South Georgia and Heard Island. On South Georgia, D. antarctica can grow but is patchy, occurring only in few, relatively protected bays where sea ice and ice from the island's calving glaciers does not regularly reach (Hay 1988). On Heard Island, populations are likewise patchy and occur only where the glaciers do not reach the shore (Klemm and Hallam 1988). Macrocystis pyrifera is not found at Heard Island (Smith 2002), but does occur at South Georgia.

Because of the extreme rarity of both $M$. pyrifera and D. antarctica growing below the APF, we are confident that our observations of these species south of the APF cannot be solely the result of drift kelp from South Georgia (far upstream) or Heard Island (downstream). Indeed, South Georgia is more than 4,500 km upstream of our kelp observations south of Marion Island, and has very sparse $D$. antarctica populations, yet many observations of D. antarctica were made on steaming transects from Marion Island southward across the APF, including during APF traverses. Previous oceanographic research in the region has shown that eddies of sub-Antarctic water can move through the APF in this zone. Our observations of kelp at and south of the APF are consistent with our hypothesis that eddies transport organisms through the front into Antarctic water.

\section{Appendix 2 (A2): Materials and Methods}

Survey data were collected on three research voyages aboard the SA Agulhas or SA Agulhas II: one in the South Atlantic from November 2013 to February 2014, and two in the Indian Ocean, with one in April 2008, and one from April to May 2014. All voyages crossed the APF, with observations made above and below the front (see figure 1). Floating kelp were counted during the day (roughly 6h30-17h30 local time) on transects while the ship moved at 9-12 knots (16.5-22 km. $\left.\mathrm{h}^{-1}\right)$. Observations were made from the ship's bridge (9-12 m above 
sea level), looking past the bow on the side of the ship that offered the best visibility. Kelp individuals were counted every minute by scanning a $300 \mathrm{~m}$ block perpendicular and extending forward from the bow with binoculars, but data were pooled into hourly blocks for analysis. Estimated distance (within $300 \mathrm{~m}$ ) of rafts from the ship, and size of each clump, were also recorded, although these data were not used in analyses as they were not necessary for testing our hypothesis. No records from temperate waters were included in analyses, and any records from within $5 \mathrm{~km}$ of a sub-Antarctic island (South Georgia, Marion or Prince Edward Islands) were excluded as they were unlikely to be representative of drift-kelp densities in the open ocean. Tests were made using several other island-buffer values, and 5 $\mathrm{km}$ was deemed to adequately reduce island-associated bias.

We defined the position of the APF by assessing where the frontal boundary zone separating sub-Antarctic and Antarctic waters occurred, based on Maps of Absolute Dynamic Topography (MADT) (Swart et al. 2010). MADT show surface altimetry determined by sea level anomaly added to mean dynamic topography (Rio et al. 2011). MADT are produced by CLS/Aviso, with data obtained from Jason-1, Envisat, ERS and Topex/Poseidon satellites from daily snapshots on a 0.25 degree resolution grid (http://www.aviso.altimetry.fr/en/data). MADT are used to remotely identify key oceanographic features (e.g., mesoscale fronts and eddies), and provide valuable information about the horizontal spatial structure and intensity of such features. The MADT data used for this work comprised monthly means for April 2008, December 2013 and April 2014 (to correspond with cruise dates).

We fitted generalised linear mixed models (GLMMs; Zuur et al. 2009) with a Poisson distribution (log-link) to test (i) whether there was a significant difference in the density of kelp above or below the APF, and (ii) whether density decreased with distance from the front. Our response variables were count data aggregated for each hour of the surveys. Models were offset by the area of each survey period to control for any differences. To address our questions, we (i) fitted the zone (Antarctic or sub-Antarctic) and (ii) the distance from the APF (both values based on front position at the time of each survey) as explanatory variables in separate models: [Species $\sim$ Zone $+\operatorname{offset}($ area $)+(1 \mid$ Day $)]$ and $[$ Species $\sim$ Distance + offset(area) + (1|Day)]. To control for possible non-independence among observations (aggregation of kelp rafts at sea according to fine-scale oceanographic features such as Langmuir Cells), we included survey day as a random effect for our models. We checked for over-dispersion by dividing the Pearson goodness-of-fit statistic by the residual degrees of freedom and found no values greater than one, suggesting that our data were not over- 
dispersed (McCullagh and Nelder 1989). We inspected the residual vs. fitted plots of each model to confirm that residuals were approximately randomly distributed with respect to fitted values (see below). We fitted models using the lme4 package for R (Bates et al. 2015).

\section{Appendix 3 (A3): Results}

Table: Results of GLMM analyses.

\begin{tabular}{llrrrr}
\hline Response & Model terms & Estimate & SE & F & P \\
\hline \multirow{2}{*}{ Macrocystis } & & & & & \\
& Zone & 3.232 & 1.027 & 3.148 & 0.002 \\
& Distance & -0.824 & 0.230 & -3.589 & 0.000 \\
\multirow{4}{*}{ Durvillaea } & & & & & \\
& Zone & 1.718 & 0.402 & 4.278 & 0.000 \\
& Distance & -0.470 & 0.085 & -5.500 & 0.000 \\
\hline
\end{tabular}
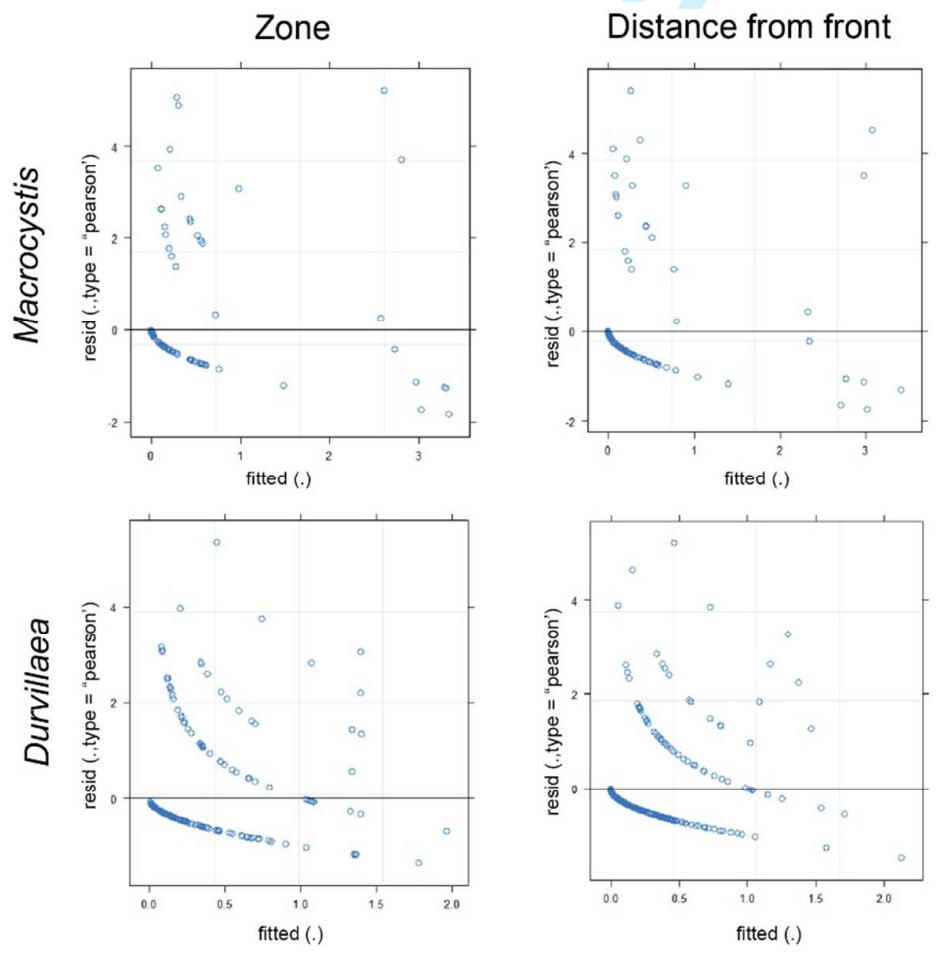

Figure: Plots of the residuals vs. fitted values for each analysis. 


\section{Appendix 4 (A4): Acknowledgements}

Logistical support was provided by the South African National Antarctic Programme. We thank Karen Ikin, Wade Blanchard and Isabelle Ansorge for advice, and Bruce Dyer, Seth Musker and Ariella Rink for assistance in the field. Thanks to Ben Raymond (Australian Antarctic Division) for creating and supplying the image of ocean currents used in Figure 1. CIF was supported by an Australian Research Council Discovery Early Career Research Award (DE140101715).

\section{Appendix 5 (A5): References for Supplementary Material}

Bates, D., Maechler, M., Bolker, B. and Walker, S. 2015. Fitting linear mixed-effects models using lme4. - Journal of Statistical Software 67: 1-48.

Burnham, K. and Anderson, D. 2002. Model selection and multimodel inference. - SpringerVerlag.

Fraser, C. I. et al. 2009. Kelp genes reveal effects of subantarctic sea ice during the Last Glacial Maximum. - Proceedings of the National Academy of Sciences of the United States of America 106: 3249-3253.

Hay, C. H. 1988. The occurrence of Durvillaea antarctica (Durvillaeales, Phaeophyta) at South-Georgia, South-Atlantic Ocean. - Phycologia 27: 424-427.

Helmuth, B., Veit, R. R. and Holberton, R. 1994. Long-distance dispersal of a subantarctic brooding bivalve (Gaimardia trapesina) by kelp-rafting. - Marine Biology 120: 421426.

Klemm, M. F. and Hallam, N. D. 1988. Standing crop of Durvillaea antarctica (Chamisso) Hariot (Phaeophyta) on the Australian Sub-Antarctic Macquarie and Heard Islands. Phycologia 27: 505-509.

Macaya, E. C. and Zuccarello, G. C. 2010. Genetic structure of the giant kelp Macrocystis pyrifera along the southeastern Pacific. - Marine Ecology Progress Series 420: 103 112.

McCullagh, P. and Nelder, J. 1989. Generalized linear models, 2nd edn. - Chapman \& Hall, London.

Rio, M.H., Guinehut, S., and Larnicol, G. 2011. New CNES-CLS09 global mean dynamic topography computed from the combination of GRACE data, altimetry, and in situ measure- ments. - Journal of Geophysical Research 116: C07018. 
Smith, S. D. A. 2002. Kelp rafts in the Southern Ocean. - Global Ecology and Biogeography 11: 67-69.

Swart, S. et al. 2010. An altimetry-based gravest empirical mode south of Africa: 1. Development and validation. - Journal of Geophysical Research 115: C03002.

Wichmann, C. S., Hinojosa, I. A. and Thiel, M. 2012. Floating kelps in Patagonian Fjords: an important vehicle for rafting invertebrates and its relevance for biogeography. Marine Biology 159: 2035-2049.

Zuur, A., Ieno, E., Walker, N., Saveliev, A. and Smith, G. 2009. Mixed effects models and extensions in ecology with R. - Springer. 